\title{
Sudden Unexpected Death in a Child with Vomiting and Diarrhea due to Intracranial Mass Lesion
}

\author{
Acile Kusma ve İshalle Başvuran Çocuğun Intrakraniyal Kitleye Bağlı Ani \\ Beklenmedik Ölümü
}

\author{
Esra Betül Akkoyun ${ }^{1}$, Sena Cantaş Örsdemir2 ${ }^{2}$, Okşan Derinöz ${ }^{3}$ \\ ${ }_{1}^{1}$ Gazi University Faculty of Medicine, Department of Pediatrics, Ankara, Turkey \\ ${ }^{2}$ Baystate Medical Center, Clinic of Pediatric Endocrinology, Massachusetts, USA \\ ${ }^{3}$ Gazi University Faculty of Medicine, Department of Pediatric Emergency, Ankara, Turkey
}

\section{Abstract}

Nausea and vomiting are common sequelae of a multitude of disorders that can range from mild to severe conditions. Intracranial mass lesions can occasionally present with vomiting followed by acute neurological deterioration and sudden death, although they are usually accompanied by ongoing neurological symptoms. We aimed to report an unusual presentation of an intracranial mass resulting in death to increase awareness among pediatric emergency physicians. A previously healthy 15-month-old boy presented to the pediatric emergency department (PED) with nausea, vomiting and diarrhea. He did not have any symptom of a neurological disorder. He acutely deteriorated, developed cardiopulmonary arrest and was intubated. His cranial computed tomography showed dilatation of the third and the lateral ventricles caused by a $3 \times 4 \times 2 \mathrm{~cm}$ tumor in the posterior fossa with an evidence of hemorrhage in the tumor with minimal tonsillar herniation. An emergent extra-ventricular drainage was performed to relieve elevated intracranial pressure. He did not show any improvement and died 9 hours after admission. Common symptoms in PED like nausea and vomiting are mostly due to benign etiologies such as gastroenteritis. One should always keep in mind that there may be an underlying intracranial pathology and further investigation should not be delayed.

Keywords: Child, sudden death, intracranial mass

\section{Öz}

Bulantı ve kusma hafiften şiddetli durumlara kadar değişebilen çok sayıda hastalığın ortak semptomudur. Intrakraniyal kitle lezyonları bazen kusma ve bunu takiben akut nörolojik bozulma ve ani ölümle birlikte ortaya çıkabilir. Buna genellikle devam eden nörolojik bulgular eşlik eder. Bu çalışmada çocuk acil hekimleri arasında bilinç düzeyini artırmak için ölümle sonuçlanan intrakraniyal bir kitlenin alışımadık bir sunumunu rapor etmeyi amaçladık. Daha önce sağlıklı olan 15 aylık bir erkek çocuk, çocuk acil servisine (ÇAS) bulantı, kusma ve ishal ile başvurdu. Herhangi bir nörolojik semptomu yoktu. Genel durumu aniden bozulan, kardiyopulmoner arrest geliştiren hasta entübe edildi. Beyin bilgisayarlı tomografisinde lateral ve üçüncü ventrikülde genişlemeye yol açan, posterior fossa'da $3 \times 4 \times 2 \mathrm{~cm}$ tümor saptandı. Tümör içinde minimal tonsiller herniasyona yol açan hemorajik alan görüldü. Artmış intrakraniyal basıncı azaltmak için acil ekstra ventriküler drenaj yapıldı. Gerekli tüm müdahalelere rağmen hasta 9 saat içinde kaybedildi. ÇAS'de bulantı ve kusma gibi sık görülen semptomlar, çoğunlukla gastroenterit gibi benign etiyolojilerden kaynaklanmaktadır. Bu tip hastalarda altta yatan intrakraniyal bir patolojinin olabileceği ve daha fazla araştırmanın geciktirilmemesi gerektiği akılda tutmalıdır.

Anahtar Kelimeler: Çocuk, ani ölüm, intrakraniyal kitle

\section{Introduction}

Sudden unexpected death is defined as death occurring within 24 hours of onset of symptoms in an previously apparently well individuals. ${ }^{1}$ The most common reasons include cardiovascular, respiratory, and infectious etiologies, especially in infants. Central nervous system (CNS) diseases, such as space-occupying lesions, infarction, meningitis, and epilepsy, rarely cause sudden unexpected death in infants..$^{2}$ The majority of the deaths due to intracranial mass lesions occur with progression of the disease or complications of the treatment. However, in some cases, intracranial mass is not identified and patients die in a very short time following the diagnosis. ${ }^{3,4}$

We present this case to stress the possibility of intracranial mass in pediatric patients undiagnosed prior to terminal

Address for Correspondence/Yazışma Adresi: Esra Betül Akkoyun MD, Gazi University Faculty of Medicine, Department of Pediatrics, Ankara, Turkey E-mail: dresrabetul@yahoo.com ORCID ID: orcid.org/0000-0001-7348-0656 Received/Geliş Tarihi: 10.01.2017 Accepted/Kabul Tarihi: 31.05.2017

${ }^{\circ}$ Copyright 2017 by Society of Pediatric Emergency and Intensive Care Medicine Journal of Pediatric Emergency and Pediatric Intensive Care published by Galenos Yayınevi. 
collapse, where the child died suddenly and unexpectedly with an intracranial mass lesion.

\section{Case}

A previously healthy 15-month-old boy presented to the pediatric emergency department (PED) with nausea and vomiting. He was in his usual state of health until 2 days prior to his presentation where he began to vomit. Reportedly, his vomiting was non-bloody, non-bilious and not projectile and followed by 2 episodes of watery stool. His mother denied fever and respiratory symptoms. He did not have any neurologic symptoms. On the day of presentation, he looked tired and weak which prompted his mother to bring him to PED. Upon arrival, his Glasgow Coma scale (GCS) score was 13 , temperature $-36.5^{\circ} \mathrm{C}$, respiratory rate $-38 /$ minute, heart rate $-130 /$ minute (tachycardia), and blood pressure was 100/60 mm/Hg. The head and neck examination revealed normocephalic and atraumatic head. His pupils were equal, round, and reactive to light. The anterior fontanel was open and flat, there was no bulging. He had sunken eyeballs and dry oral mucosa. No nuchal rigidity was noted. His chest was clear to auscultation bilaterally. His initial neurologic examination was normal. His skin examination did not reveal any rash or hypo/hyperpigmented lesion but he had decreased skin turgor and the capillary refill over three seconds. Other system findings were essentially normal.

The patient was admitted to the emergency observation unit with moderate dehydration due to diarrhea and vomiting. Prior to intravenous (IV) fluid therapy, blood tests were performed to determine the possible electrolyte imbalance. His glucose level was $96 \mathrm{mg} / \mathrm{dL}$. Laboratory tests were as follows: white blood cells: $12.900 / \mathrm{mm}^{3}$, hemoglobin: $10 \mathrm{~g} / \mathrm{dL}$ and platelets: $203.000 / \mathrm{mm}^{3}$. Blood chemistry showed the followings: blood urea nitrogen: $22 \mathrm{mg} / \mathrm{dL}$, creatinine: $0.63 \mathrm{mg} / \mathrm{dL}$, calcium: $10.50 \mathrm{mg} / \mathrm{dL}$, sodium: $136 \mathrm{mmol} / \mathrm{L}$, and potassium: 4.30 $\mathrm{mmol} / \mathrm{L}$. There was no electrolyte imbalance. Urine analysis showed: specific gravity: 1020, white blood cell: 7/ highpower field (hpf), red blood cell: 0/hpf, leucocyte esterase: negative, nitrite: negative, and ketone: $3^{+}$. Venous blood gas analysis revealed the following values: $\mathrm{pH}: 7.41, \mathrm{pCO}_{2}: 29.6$, $\mathrm{HCO}_{3}: 18.7, \mathrm{BE}:-4.2$, and lactate: 2.8 . Patient history, physical examination findings and laboratory findings were accepted as compensated shock. Serum physiologic therapy was given as of $20 \mathrm{cc} / \mathrm{kg}$ IV bolus immediately after blood tests were performed. Then, $100 \mathrm{cc} / \mathrm{kg}$ increased maintenance and deficit treatment were started. During the follow-up in the emergency observation unit, skin turgor and capillary refill time improved. Three hours after his admission, he had a generalized tonic-clonic seizure that lasted 30 seconds. The seizure stopped after $0.1 \mathrm{cc} / \mathrm{kg}$ IV midazolam administration. $\mathrm{He}$ had another generalized tonic-clonic seizure 30 minutes after the first seizure. It lasted 1.5 minutes and stopped after $0.1 \mathrm{cc} / \mathrm{kg}$ IV midazolam administration. His clinical condition deteriorated after the seizure. The vital signs of the patient were as follows: pulse rate: 184/ minute, respiratory rate: $36 /$ minute, and systolic blood pressure: $70 \mathrm{mmHg}$. The patient's capillary refill time was 3 seconds and cyanosis was present. The patient was given $20 \mathrm{cc} / \mathrm{kg}$ saline therapy for the second time. Dopamine infusion was initiated due to the lack of clinical response to fluid therapy and continued hypotension. There was no reason explaining hypotension in the patient with normovolemic situation (during the follow-up in the emergency observation unit, skin turgor and capillary refill time improved) and sympathetic tonus increased. The cause of hypotension was not understood after second convulsion. May be it was due to midazolam. GCS was 4 following the second seizure. He had a prolonged post-ictal period and was not able to regain his consciousness. There was no pupillary light reflex bilaterally. His deep tendon reflexes were absent. He acutely deteriorated, was intubated immediately and developed cardiopulmonary arrest 15 minutes after his second seizure.

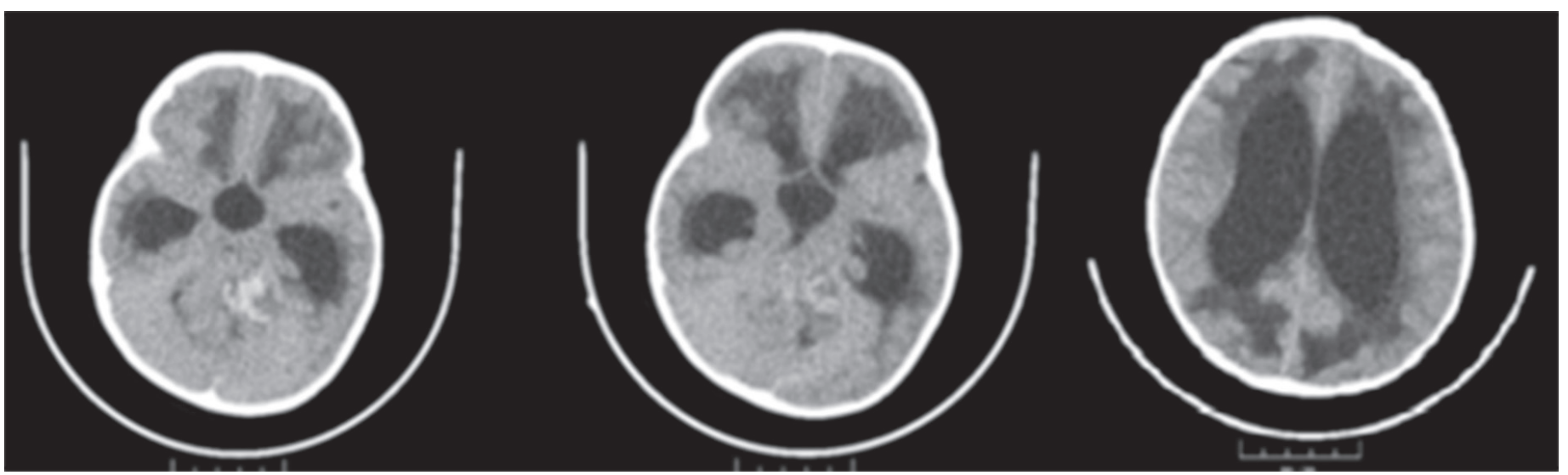

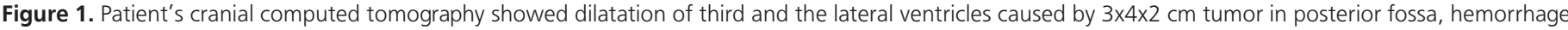
inside a tumor with minimal tonsillar herniation 
Further discussion with his family revealed that the patient was reluctant to walk since last month and he became significantly inattentive since last week.

Cranial imaging was done because the patient's seizures were afebrile; no other cause or biochemical abnormality was found. Cranial computed tomography showed dilatation of the third and the lateral ventricles caused by a $3 \times 4 \times 2$ $\mathrm{cm}$ tumor in the posterior fossa, and hemorrhage inside the tumor with minimal tonsillar herniation (Figure 1). The patient was started with anti-edema (methylprednizolone) treatment. He was transferred to the pediatric intensive care unit. An emergent extra-ventricular drainage was performed to relieve intracranial pressure (ICP). He died nine hours after the admission to the hospital despite aggressive respiratory and circulatory support including intubation and mechanical ventilation, administration of inotropic agents and antibiotics.

Tissue diagnosis was not available because his parents did not give permission for autopsy.

\section{Discussion}

Gastroenteritis is by far the most common disorder presenting with vomiting in infants, children, and adolescents. Gastroesophageal reflux disease, gastroparesis, mechanical obstruction, anaphylaxis, Munchausen syndrome by proxy (factitious disorder by proxy), intracranial masses, peptic ulcer disease, cyclic vomiting, and diabetic ketoacidosis also may be diagnostic considerations. ${ }^{5}$ We present a patient who had vomiting that was misinterpreted as gastroenteritis. After his clinical deterioration, it was understood that vomiting was due to a cranial mass.

Clinical symptoms of intracranial masses differ with patient's age and type of tumor and are generally non-specific. ${ }^{3}$ In a systematic review with CNS tumors, headache (33\%), nausea and vomiting (32\%) and unspecified symptoms and signs of ICP (10\%) were the most common symptoms. ${ }^{5}$ In the same study, symptoms of children under four years of age were listed as macrocephaly (41\%), nausea and vomiting (30\%) and irritability (24\%). ${ }^{5}$ In these studies ${ }^{3,5}$, it is examined that the symptoms accompanied by an intracranial mass and it is reported vomiting and nausea in most cases. In our case, the patient had nausea, vomiting, inattention, seizure and lethargy. Nausea and vomiting are nonspecific symptoms of ICP due to intracranial mass and are commonly present in children with CNS tumors, especially posterior fossa tumors. ${ }^{6}$ However, when a previously healthy patient presents to PED with these complaints, physicians immediately consider infections of the gastrointestinal system. Pediatric emergency physicians should be vigilant, and aware of the fact that vomiting and nausea are not stimulated only by one system.
In a child or infant presenting to PED with vomiting, duration of vomiting and focal gastrointestinal system symptoms are crucial for definitive diagnosis. ${ }^{5}$ Vomiting for more than 12 hours in a newborn, 24 hours in children under two years of age, and 48 hours in other children should be taken into consideration. ${ }^{3,7}$ In our case, the patient's vomiting lasted 12 hours. Sudden, unexpected death due to a CNS mass in a previously healthy individual is a rare event. Such cases have scarcely been published in the literature. Frequency of sudden, unexpected death due to a primary CNS mass is in the range of $0.11 \%$ to $0.24 \%$ in forensic autopsy series. ${ }^{8.14}$ Symptoms and death occur in patients with intracranial mass since it increases ICP and leads to cerebral herniation. A small CNS mass placed in pathophysiological critical points blocks cerebrospinal fluid (CSF) or even if it does not block CSF, it may increase ICP and lead to herniation. 4,10,11,14 Epileptic seizures caused by CNS tumors are also considered to be a cause of sudden death. ${ }^{11,12}$ Especially infra-tentorial tumors can affect cardiac and respiratory centers, and lead to sudden death. ${ }^{15}$ In our case, the tumor blocked the CSF after increasing CSF pressure and eventually resulted in cerebral herniation. And it may lead to seizure, cardiac and respiratory arrest and sudden death.

The primary questions should be "Can we diagnose increased ICP before reaching the irreversible term? Can a pediatric emergency physician easily diagnose in cases having nonspecific symptoms?" In some patients, symptoms are so nonspecific that it is impossible to locate the mass and this may delay the diagnosis. For true diagnosis in cases with above mentioned symptoms, a CNS mass should also be kept in mind while evaluating the detailed history.

In such cases with nausea and vomiting without any other gastrointestinal system findings like abdominal defense and rebound, the most basic point is that vomiting and nausea could be a hint for neurological illnesses. Increased ICP due to intracranial masses is the main cause of nausea and vomiting. For this reason, it is necessary to search carefully for the findings of the ICP increase. For the cases with more than one or two days without diarrhea, we should investigate more and consider etiologies other than gastroenteritis. ${ }^{8}$

In conclusion, symptoms like vomiting and nausea that commonly encountered in PEDs are not only related with the gastrointestinal system. In cases with nausea and vomiting without any other gastrointestinal system findings like abdominal defense and rebound, other organ systems should be considered. We should keep in mind that CNS masses can lead to sudden and unexpected deaths; and clinical symptoms are usually non-specific in such cases that make definitive diagnosis difficult. 


\section{Ethics}

Informed Consent: We obtained informed consent from the child's parents.

Peer-review: Externally and Internally peer-reviewed.

\section{Authorship Contributions}

Surgical and Medical Practices: O.D., E.B.A., Concept: O,D., E.B.A., Data Collection or Processing: O.D., E.B.A., S.C.Ö., Analysis or Interpretation: O.D., E.B.A., S.C.Ö., Literature Search: O.D., E.B.A., E.B.A.

Conflict of Interest: No conflict of interest was declared by the authors.

Financial Disclosure: The authors declared that this study received no financial support.

\section{References}

1. Byard RW, Bourne AJ, Hanieh A. Sudden and unexpected death due to hemorrhage from occult nervous system lesions. A pediatric autopsy study. Pediatr Neurosurg. 1991;17:88-94.

2. Denfield SW, Garson A Jr. Sudden death in children and young adults. Pediatr Clin North Am. 1990;37:215-31.

3. Eberhart CG, Morrison A, Gyure KA, Frazier J, Smialek J, et al. Decreasing incidence of sudden death due to undiagnosed primary central nervous system tumours. Arch Pathol Lab Med. 2001;125:1024-30.

4. Elgamal EA, Richards PG. Sudden death in children due to intracranial mass lesion. Childs Nerv Syst. 2006;22:305-9.

5. Uptodate Web Site, Carlo Di Lorenzo, Approach to the infant or child with nausea and vomiting, 2015 Available at http://www. uptodate.com/contents/approach-to-the-infant-or-child-withnausea-and-vomiting, updated June 2015.

6. Uptodate Web Site, Ching Lau, Clinical manifestations and diagnosis of central nervous system tumors in children, 2015 Avaliable at http://www.uptodate.com/contents/clinical-manifestations-anddiagnosis-of-central-nervous-system-tumors-in-children, updated Nov 2015.

7. Wilne S, Collier J, Kennedy C, Koller K, Grundy R, et al. Presentation of childhood CNS tumours: a systematic review and meta-analysis. Lancet Oncol. 2007;8:685-95.

8. Shemie S, Jay V, Rutka J, Armstrong D. Acute obstructive hydrocephalus and sudden death in children. Ann Emerg Med. 1997;29:524-8.

9. Hutington RW Jr, Cummings $\mathrm{KL}$, Moe TI, O'Connell HV, Wybel R. Discovery of fatal primary intracranial neoplasms at medicolegal autopsies. Cancer. 1965;18:117-27.

10. Murphy GK. Cancer and coroner. JAMA. 1977;74:786-8.

11. DiMaio SM, DiMaio VJ, Kirkpatrick JB. Sudden, unexpected deaths due to primary intracranial neoplasms. Am J Forensic Med Pathol. 1980;1:29-45.

12. Takatsu A, Kurihara T, Ishiyama I. Sudden death due to brain tumor: a survey of 56 autopsy cases. Jpn J Legal Med. 1980;34:683-93.

13. Abu Al Ragheb SY, Koussous KJ, Amr SS. Intracranial neoplasms associated with sudden death: a report of seven cases and a review of the literature. Med Sci Law. 1986;26:270-2.

14. Bunai $Y$, Akaza $K$, Tsujinaka $M$, Nakamura I, Nagai A. Sudden Death Due to Undiagnosed Intracranial Hemangiopericytoma. Am J Forensic Med Pathol. 2008;29:170-2.

15. Poon TP, Solis OG. Sudden death due to massive intraventricular hemorrhage into an unsuspected ependymoma. Surg Neurol. 1985;24:63-6. 